\title{
Role of calcium in adhesion and germination of zoospore cysts of Pythium: a model to explain infection of host plants
}

\author{
S. P. Donaldson* and J. W. Deacon \\ Institute of Cell and Molecular Biology, University of Edinburgh, Daniel Rutherford Building, King's Buildings, \\ Mayfield Road, Edinburgh EH9 3JH, UK
}

(Received 17 February 1992; revised 3 June 1992; accepted 23 June 1992)

\begin{abstract}
Newly-formed zoospore cysts of Pythium aphanidermatum adhered to glass and germinated without a further trigger, but both adhesion and germination were suppressed by EGTA. Older $(10 \mathrm{~min})$ cysts adhered and germinated poorly unless supplied with $\mathrm{Ca}^{2+}$. Adhesion and germination were linked but separable, because young cysts germinated when dislodged from glass after $10 \mathrm{~min}$, and older cysts kept in suspension germinated in response to high (7-10 mM) concentrations of $\mathrm{Ca}^{2+}, \mathrm{Mg}^{2+}$ or $\mathrm{Sr}^{2+}$. Other cations $\left(\mathrm{Li}^{+}, \mathrm{Na}^{+}, \mathrm{K}^{+}, \mathrm{Ba}^{2+}, \mathrm{Mn}^{2+}, \mathrm{Fe}^{3+}, \mathrm{Cu}^{3+}\right)$ had no effect up to $25 \mathrm{mM}$ concentration or were toxic. The naturally low germination of suspended cysts was suppressed by EGTA (chelator), $\mathrm{La}^{3+}$ or verapamil $\left(\mathrm{Ca}^{2+}\right.$ entry blockers), amiloride ( $\mathrm{Ca}^{2+}$ flux inhibitor), trifluoperazine or dibucaine (calmodulin antagonists), TMB-8 (intracellular $\mathrm{Ca}^{2+}$ antagonist) or $\mathrm{A23187}\left(\mathrm{Ca}^{2+}\right.$ ionophore). Suppression by TMB-8 or A23187 was not relieved by any post-treatment. Suppression by EGTA was relieved only by divalent cations. Suppression by all other compounds was relieved only by specific L-amino acids that stimulated germination of control cysts (asparagine, aspartic acid and glutamic acid but not lysine or glutamine, where tested). Alanine relieved suppression by verapamil or dibucaine in Pythium dissotocum but not $P$. aphanidermatum. The findings indicated a central role of $\mathrm{Ca}^{2+}$ (presumably released during encystment) in adhesion and germination, such that zoospores would germinate autonomously by a $\mathrm{Ca}^{2+}$-mediated cascade when they dock and encyst on roots with the fixed point of germination adjacent to the host. Amino acids are not essential but apparently synergize this process by species-specific receptor-binding which facilitates $\mathrm{Ca}^{2+}$ uptake or $\mathrm{Ca}^{2+}$ signalling.
\end{abstract}

\section{Introduction}

Zoospores of soil-borne Oomycetes (Pythium, Phytophthora, Aphanomyces spp.) are attracted to roots by chemotaxis and then undergo a developmental sequence leading to infection (Deacon, 1988). They search the root surface for a suitable site, then dock, encyst and adhere with precise orientation, so that the germ-tube emerges from a pre-determined point next to the host and immediately initiates penetration (Mitchell \& Deacon $1986 a$; Hardham \& Gubler, 1990; Jones et al., 1991). Several stages of this sequence can be simulated in vitro and some of the potential host-derived triggers or elicitors have been identified (e.g. Hinch \& Clarke, 1980; Mitchell \& Deacon, 1986 b, $c$; Longman \& Callow, 1987; Jones et al., 1991). However, it is unclear whether the

\footnotetext{
* Author for correspondence: Tel. 031650 5347; fax 0316505392.

Abbreviations: SDW, sterile distilled water; TFP, trifluoperazine dihydrochloride; TMB-8, 8-(diethylamino)-octyl-3,4,5-trimethoxybenzoate hydrochloride.
}

stages of the sequence are necessarily under separate control or are parts of a cascade. This is important because the success of infection depends on completion of the sequence.

Early in encystment, zoospores release glycoprotein by exocytosis of vesicles (Sing \& Bartnicki-Garcia, 1975; Gubler \& Hardham, 1988, 1991; Estrada-Garcia et al., 1990). The glycoprotein forms the cyst coat beneath which the cyst wall is formed. It also serves as a nonspecific adhesive, attaching the newly formed cyst to the host or other types of surface. In Phytophthora cinnamomi the glycoprotein released over the germination site is immunologically distinct from that over the rest of the cyst (Hardham \& Gubler, 1990). An immunological difference was not found in Pythium aphanidermatum (Estrada-Garcia et al., 1990). Nevertheless, both fungi germinate from the same region, corresponding to the former ventral groove of the zoospore (Paktitis et al., 1986; Jones et al., 1991). For both, therefore, the functional adhesive in vivo is that which is deposited over the germination site. 
Calcium has been implicated in adhesion of $P h$. cinnamomi (Gubler et al., 1989). Newly-formed cysts were naturally adhesive, but this property was lost on addition of EGTA, which chelates $\mathrm{Ca}^{2+}$. Conversely, cysts lost their natural adhesiveness if they did not contact a surface within a few minutes, but this could be restored by addition of $\mathrm{Ca}^{2+}$. It was proposed that the glycoprotein becomes adhesive when it interacts with $\mathrm{Ca}^{2+}$ (Gubler et al., 1989), which was shown to be released in the early stages of encystment of $P h$. palmivora (Irving et al., 1984). The loss of adhesiveness in the absence of a surface was ascribed to dispersion of this released $\mathrm{Ca}^{2+}$ or, perhaps, its reabsorption. High levels of $\mathrm{Ca}^{2+}$ also induced encystment followed by 'spontaneous' germination of Phytophthora spp. in vitro, whereas most other ions induced encystment without germination (Byrt et al., 1982; Irving \& Grant, 1984; Grant et al., 1986). These findings suggest that $\mathrm{Ca}^{2+}$ could provide the link in a possible cascade initiated by docking. In order to establish this, it is necessary to show a direct relationship between calcium, adhesion and germination, and also, ideally, to account for the roles of other factors such as root-derived amino acids which influence the infection sequence (Jones et al., 1991). We have now done this for Pythium spp. in vitro, and the results suggest a simple model of $\mathrm{Ca}^{2+}$-mediated autoregulation.

\section{Methods}

Fungal isolates and zoospore production. Pythium aphanidermatum (Edson) Fitzp. (isolate CBS 634.70) was used for most experiments, as in earlier work (Mitchell \& Deacon, $1986 a, b, c$; Jones et al., 1991). The cysts germinate in response to L-asparagine, L-glutamic acid or Laspartic acid but not other amino acids. Pythium dissotocum Drechs. and $P$. catenulatum Matthews were also used; the cultures were supplied by M. E. Stanghellini (see Goldberg et al., 1989). The cysts germinate in response to L-asparagine, $\mathrm{L}$-glutamic acid, $\mathrm{L}$-aspartic acid, $\mathrm{L}$-alanine and $(\boldsymbol{P}$. catenulatum only) $\mathrm{L}$-glutamine. All fungi were grown at $25^{\circ} \mathrm{C}$ on plates of V8 agar comprising Campbells V8 juice $(100 \mathrm{ml})$, distilled water $(900 \mathrm{ml})$ and Oxoid no. 3 agar $(20 \mathrm{~g})$. For production of zoospores, agar blocks $(15 \mathrm{~cm} \times 15 \mathrm{~cm})$ were cut from colonies respectively 3,5 and $7 \mathrm{~d}$ old and placed, six per dish, in $9 \mathrm{~cm}$ Petri dishes containing $20 \mathrm{ml}$ sterile distilled water (SDW). Zoospores were released when cultures were incubated on a laboratory bench (16$20^{\circ} \mathrm{C}$ ) and used after about $6 \mathrm{~h}$, when there were at least $10^{5}$ zoospores $\mathrm{ml}^{-1}$. Unless otherwise stated, the suspensions were standardized by dilution with SDW to $2 \times 10^{4}$ zoospores $\mathrm{ml}^{-1}$.

Encystment, adhesion and germination. Encystment was induced when an Eppendorf tube of zoospore suspension was held against a vortex mixer for $70 \mathrm{~s}$ (Tokunaga \& Bartnicki-Garcia, 1971). The suspension was then incubated at room temperature in Eppendorf tubes or after transfer at different times to the wells of glass depression slides. Treatments were applied as detailed below; all supplements were adjusted to $\mathrm{pH} 7$ with $\mathrm{NaOH}$ before use. Germination was assessed after $1.5 \mathrm{~h}$, using a Leitz Orthoplan microscope with a video camera attachment (Jones et al., 1991). Cells were scored as germinated when the germ-tube length at least equalled the cyst diameter (approx. $10 \mu \mathrm{m})$. Adhesion was assessed by comparing numbers of cells on a slide before and after rinsing, described below. Then the slides were usually re-incubated in a humid chamber and re-assessed after $16 \mathrm{~h}$.

Statistical methods. All treatments were replicated at least five times and, unless otherwise stated, 100 cysts were assessed for each replicate. Percentage adhesion or germination was recorded as mean \pm standard error of the mean (SEM). Statistical comparisons were made by paired $t$ tests (Snedecor \& Cochrane, 1980) which are more sensitive than conventional $t$-tests. Pairing was necessary because the time constraints for assessment of germination meant that each experiment had to be done five or more times with a single replicate each time.

Relationship between adhesion and germination. Aliquots ( $80 \mu \mathrm{l})$ of cyst suspension were transferred to welled slides immediately $\left(t_{0}\right)$ or $10 \mathrm{~min}$ $\left(t_{10}\right)$ after vortexing to induce encystment, from the same position in an Eppendorf tube. In each case, control slides immediately received $80 \mu \mathrm{l}$ SDW; treatment slides immediately received $80 \mu \mathrm{CaCl}_{2}$ solution or $80 \mu$ l EGTA solution or ( $t_{0}$ samples only) $80 \mu$ l EGTA after $10 \mathrm{~min}$ delay. Each supplement was used at $7 \mathrm{mM}$ final concentration. The number of cells on each slide and the number that had germinated were scored after $1.5 \mathrm{~h}$. Then the liquid with non-adherent cells was removed by pipette, $160 \mu \mathrm{l}$ SDW was added and similarly removed, this was repeated, and $160 \mu \mathrm{l}$ SDW was finally added. Slides were then reassessed for the numbers of remaining cells and the numbers of these that had germinated.

To determine the time at which cysts lost their adhesiveness, aliquots of cyst suspension were transferred to slides immediately $\left(t_{0}\right)$ or at $1 \mathrm{~min}$ intervals up to $10 \mathrm{~min}$. Either EGTA solution (final concn $7 \mathrm{~mm}$ ) or SDW was added, and germination was scored after $2 \mathrm{~h}$.

The effect of dislodgement of cysts on germination was tested with cyst suspension $\left(160 \mu \mathrm{l}, 2 \times 10^{5}\right.$ cysts $\left.\mathrm{ml}^{-1}\right)$ that was added immediately to slides and rinsed with SDW after $10 \mathrm{~min}$ to remove non-adherent cysts. Then SDW $(160 \mu \mathrm{l})$ was added and the wells were scraped with a sharp scalpel to dislodge some cysts. Eighty microlitres of water containing dislodged cysts was added to a fresh slide. The remaining water was removed from each original slide, leaving only attached cysts, and replaced with $80 \mu \mathrm{l} \mathrm{SDW}$. Both sets of slides (representing detached and attached cells, respectively) were scored for germination after $1.5 \mathrm{~h}$, then rinsed and scored for residual adhesion, using a video camera to locate the same microscope fields. The same experiment was done with cysts added to slides $10 \mathrm{~min}$ after vortexing but immediately rinsed to remove non-adherent cysts (the majority).

Effects of ions and EGTA on germination of suspended cysts. Immediately after vortexing, cyst suspensions $(150 \mu \mathrm{l})$ of three Pythium spp. in Eppendorf tubes received an equal volume of SDW (control) or solutions of $\mathrm{CaCl}_{2}, \mathrm{MgCl}_{2}, \mathrm{SrCl}_{2}, \mathrm{MnCl}_{2}, \mathrm{BaCl}_{2}, \mathrm{KCl}, \mathrm{NaCl}, \mathrm{LiCl}$, $\mathrm{FeCl}_{3}$ or $\mathrm{CrCl}_{3}$, each at $1,5,7,10$ and $25 \mathrm{~mm}$ final concentration. The contents were mixed by inversion three times, and germination was scored after $1.5 \mathrm{~h}$ by transferring the $150 \mu \mathrm{l}$ samples to a welled slide. The slides were reassessed after $16 \mathrm{~h}$ in a humid chamber. In a similar experiment, fresh cysts in Eppendorf tubes received one of the following ( $7 \mathrm{mM}$ final concentration): EGTA, EGTA $+\mathrm{CaCl}_{2}$, EGTA $+\mathrm{MgCl}_{2}, \quad$ EGTA $+\mathrm{SrCl}_{2}, \quad$ EGTA $+\mathrm{KCl}, \quad$ EGTA $+\mathrm{NaCl}$, SDW (control). The salts and EGTA had been mixed and incubated in solution for $24 \mathrm{~h}$ before use. The same treatments were also applied to motile zoospore suspension in welled slides; both percentage encystment and percentage germination were assessed after $1.5 \mathrm{~h}$ and $16 \mathrm{~h}$.

Effect of lanthanum on germination. Cysts of $P$. aphanidermatum (0.5 $\mathrm{ml}$ ) were incubated in Eppendorf tubes for $10 \mathrm{~min}$. Then $0.5 \mathrm{ml}$ SDW (control) or $0.5 \mathrm{ml} \mathrm{LaCl}$ solution ( $1.5 \mathrm{mM}$ final concentration) was added and mixed by inversion. After a further $10 \min \left(t_{20}\right) 80 \mu \mathrm{l}$ aliquots were then transferred to further tubes which received the following (final concentrations): $\mathrm{CaCl}_{2}(10 \mathrm{mM}), \mathrm{SrCl}_{2}(10 \mathrm{mM}), \mathrm{MgCl}_{2}$ (10 mM), $\mathrm{CaCl}_{2}(10 \mathrm{mM})+\mathrm{LaCl}_{3}(1.5 \mathrm{mM}), \mathrm{LaCl}_{3}(1.5 \mathrm{mM}), \mathrm{MEP}(3 \%$ malt extract and $1 \%$ peptone), SDW (control). Each treatment (SDW 
Table 1. Relationship between adhesion and germination of cysts of Pythium aphanidermatum

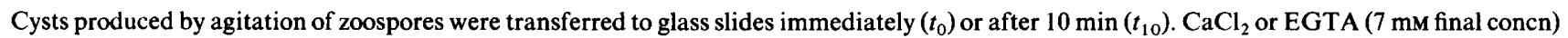
was added to the slides immediately or after a 10 min delay. Percentage germination and adhesion after $1.5 \mathrm{~h}$ are shown as mean \pm SEM for seven replicates.

Cyst age (min) at transfer, and treatment:

\begin{tabular}{lcccccc}
\cline { 2 - 6 } & & & & & & \\
$t_{0}$ & $t_{10}$ & $t_{0}+\mathrm{Ca}^{2+}$ & $t_{10}+\mathrm{Ca}^{2+}$ & $t_{0}+$ EGTA & $\begin{array}{c}t_{0}+\text { EGTA } \\
\text { delayed }\end{array}$ \\
\hline No of spores & $188 \pm 30$ & $171 \pm 29$ & $185 \pm 16$ & $150 \pm 19$ & $143 \pm 13$ & $147 \pm 15$ \\
Germination (\%) & $59 \pm 7$ & $25 \pm 5$ & $59 \pm 6$ & $54 \pm 5$ & $10 \pm 3$ & $20 \pm 4$ \\
Adhesion (\%) & $59 \pm 7$ & $30 \pm 7$ & $61 \pm 5$ & $62 \pm 5$ & $21 \pm 4$ & $21 \pm 3$ \\
$\begin{array}{l}\text { Germination (\%) } \\
\text { after washing }\end{array}$ & $69 \pm 5$ & $51 \pm 5$ & $65 \pm 7$ & $63 \pm 4$ & $48 \pm 8$ & $51 \pm 7$ \\
$\begin{array}{l}\text { Germinated cysts retained } \\
\text { after washing (\%) }\end{array}$ & $71 \pm 5$ & $62 \pm 8$ & $67 \pm 6$ & $75 \pm 5$ & $75 \pm 6$ & $61 \pm 6$ \\
$\begin{array}{l}\text { Non-germinated cysts } \\
\text { retained after washing (\%) }\end{array}$ & $47 \pm 7$ & $23 \pm 8$ & $47 \pm 3$ & $45 \pm 8$ & $11 \pm 3$ & $12 \pm 2$ \\
\hline \hline
\end{tabular}

or $\mathrm{LaCl}_{3}$ ) thus had seven post-treatments. Germination was scored after $1.5 \mathrm{~h}$ by transferring the tube contents to welled slides, and reassesssed after $16 \mathrm{~h}$ on the slides. In a similar experiment, cysts were centrifuged at $t_{20}(3 \mathrm{~min}$ in a microfuge at 15000 r.p.m. $)$, the pellet was rinsed twice with SDW, then resuspended in SDW before posttreatment.

In identical experiments, $t_{10}$ cysts in Eppendorf tubes were treated with $\mathrm{LaCl}_{3}$ ( $1.5 \mathrm{~mm}$ final concn), EGTA ( $7 \mathrm{~mm}$ final concn) or SDW. At $t_{20}$, aliquots of these suspensions were post-treated with (mM final concn): $\mathrm{CaCl}_{2}(10)$, L-asparagine (10), L-aspartic acid (10), L-glutamic acid (10), L-glutamine (10), L-lysine (10), $\mathrm{LaCl}_{3}(1 \cdot 5)$, EGTA (7) or SDW.

Effects of calcium modulators. $t_{10}$ cysts in Eppendorf tubes were treated with SDW (control) or calcium modulators, then $\left(t_{20}\right)$ posttreated with $10 \mathrm{~mm}-\mathrm{CaCl}_{2}, \mathrm{MgCl}_{2}$ or $\mathrm{SrCl}_{2}$ or with individual L-amino acids (10 mM) known to stimulate or not to stimulate germination. The calcium modulators (Sigma; final concentration in parentheses) were verapamil hydrochloride $(30 \mu \mathrm{M})$, amiloride hydrochloride $(20 \mu \mathrm{M})$, dibucaine hydrochloride $(50 \mu \mathrm{M})$, TFP $(5 \mu \mathrm{M})$, TMB-8 $(30 \mu \mathrm{M})$ and A23187 (5 $\mu \mathrm{M})$. All except A23187 were dissolved in water and adjusted to $\mathrm{pH} 7$ with $\mathrm{NaOH}$. A23187 was initially dissolved in dimethylsulphoxide (DMSO) and then diluted to $0.05 \%(\mathrm{v} / \mathrm{v})$ DMSO in water. DMSO alone at this concentration had no effect on germination.

\section{Results}

Cysts were easily pipetted from Eppendorf tubes, and direct comparisons of samples at 0 and $10 \mathrm{~min}$ after encystment showed no significant difference in retrieval (Table 1). Cysts incubated in the tubes were therefore considered to be suspended (non-adhered).

\section{Relationship between adhesion and germination}

Cysts transferred to slides immediately after encystment $\left(t_{0}\right)$ germinated and adhered significantly better than did cysts $\left(t_{10}\right)$ transferred after $10 \mathrm{~min}$ (Table 1). Addition of EGTA to $t_{0}$ cysts immediately after transfer reduced their germination and adhesion, but EGTA had no effect on $t_{0}$ cysts when added 10 min later. $\mathrm{Ca}_{2}{ }^{+}$had no effect on $t_{0}$ cysts, but it markedly increased both germination and adhesion of $t_{10}$ cysts. There was thus a consistent association between adhesion and germination, and $\mathrm{Ca}_{2}{ }^{+}$or other divalent cations seemed to mediate both processes.

A delay of up to 4 min in transfer of cysts to slides had no adverse effect on germination (Table 2); but a delay of 7 min or more significantly reduced germination. These times also marked a change in sensitivity to EGTA, which suppressed germination of cysts transferred up to $4 \mathrm{~min}$ but had no effect at $6 \mathrm{~min}$ or later. Consistent with these findings, cysts $\left(t_{0}\right)$ that had been allowed to adhere to slides for 10 min could be physically dislodged without loss of germination, even though they did not readhere in large numbers (Table 3 ). The experiments indicated that competence to germinate was influenced by events in the first few minutes after encystment, was sensitive to interference by EGTA in this time and was associated with adhesion to a surface.

\section{Effects of ions and EGTA on germination of suspended cysts}

Cysts of three Pythium spp. held in suspension in Eppendorf tubes showed a significant increase in germination in response to $\mathrm{Ca}^{2+}, \mathrm{Mg}^{2+}$ or $\mathrm{Sr}^{2+}$ at 7-10 mM but not to $\mathrm{K}^{+}$or $\mathrm{Na}^{+}$at even $25 \mathrm{~mm}$ (Table 4). Of the three divalent cations, $\mathrm{Sr}^{2+}$ was generally least effective in stimulating germination, especially at intermediate concentrations. In identical tests (not shown) $\mathrm{Li}^{+}$and $\mathrm{Mn}^{2+}$ caused no significant response; $\mathrm{Ba}^{2+}, \mathrm{Fe}^{3+}$ and $\mathrm{Cr}^{3+}$ caused many cysts to lyse and, even at $1 \mathrm{mM}$, significantly reduced germination of the intact cysts.

EGTA significantly suppressed the germination of suspended cysts compared with that in water controls (Table 5). This suppression was relieved by simultaneous addition of divalent cations but not by $\mathrm{K}^{+}$or $\mathrm{Na}^{+}$. When 
Table 2. Effect of EGTA on germination of zoospore cysts of Pythium aphanidermatum

Cysts produced by agitation of zoospores were transferred to glass slides at different times and incubated for $2 \mathrm{~h}$ in distilled water or with EGTA (final concentration $7 \mathrm{mM}$ )

\begin{tabular}{|c|c|c|c|}
\hline \multirow{2}{*}{$\begin{array}{c}\text { Time of } \\
\text { transfer (min) }\end{array}$} & \multicolumn{2}{|c|}{ Germination $(\%) \dagger$} & \multirow{2}{*}{$\begin{array}{l}\text { Significance } \\
\text { of difference }\end{array}$} \\
\hline & Distilled water & EGTA & \\
\hline 0 & $69 \pm 5 \cdot 8$ & $14 \pm 2 \cdot 7$ & $* * *$ \\
\hline 1 & $71+5 \cdot 3$ & $14+2.9$ & **** \\
\hline 2 & $71 \pm 3.9$ & $18 \pm 3 \cdot 6$ & $* * *$ \\
\hline 3 & $70 \pm 3.0$ & $18 \pm 2.8$ & *** \\
\hline 4 & $70+3.0$ & $25+3 \cdot 2$ & **** \\
\hline 5 & $50 \pm 5.9$ & $33 \pm 4 \cdot 1$ & $*$ \\
\hline 6 & $37 \pm 5.8$ & $35 \pm 5 \cdot 7$ & NS \\
\hline 7 & $25 \pm 2 \cdot 4$ & $26 \pm 4 \cdot 8$ & NS \\
\hline 8 & $30 \pm 2.7$ & $31 \pm 3.8$ & NS \\
\hline 9 & $26 \pm 2 \cdot 1$ & $26 \pm 2 \cdot 8$ & NS \\
\hline 10 & $28+1 \cdot 3$ & $31+3 \cdot 7$ & NS \\
\hline
\end{tabular}

$\dagger$ Mean \pm SEM for nine replicate slides; 100 cysts were assessed for each replicate.

$\ddagger$ Significance of difference between columns (paired $t$-test): ***, $0.001 ; *, 0.02$; NS, not significant.

Table 3. Germination of adherent spores of Pythium aphanidermatum after detachment from glass slides

Spores encysted by agitation were added immediately $\left(t_{0}\right)$ or after $10 \mathrm{~min}\left(t_{10}\right)$ to glass slides. Some of the adherent cells were scraped from the slides and reincubated on fresh slides. Germination and adhesion were assessed after $1.5 \mathrm{~h}$ (mean \pm SEM for seven replicates, based on 100 cysts each).

\begin{tabular}{lcc}
\hline \hline $\begin{array}{c}\text { Spore age and } \\
\text { treatment }\end{array}$ & Germination (\%) & Adhesion (\%) \\
\hline$t_{0}$ & & \\
Undisturbed & $62 \pm 7 \cdot 0$ & $65 \pm 6 \cdot 2$ \\
Detached, transferred & $57 \pm 5 \cdot 2$ & $27 \pm 3 \cdot 2$ \\
$\quad$ to new slides & & \\
$t_{10}$ & & $29 \pm 3 \cdot 1$ \\
Undisturbed & $25 \pm 4 \cdot 9$ & $29 \pm 4 \cdot 2$ \\
Detached, transferred & $23 \pm 3 \cdot 2$ & \\
to new slides & & \\
\hline \hline
\end{tabular}

the same treatments were applied to motile spores on slides, EGTA alone or with any salt caused encystment of spores by $1.5 \mathrm{~h}$ whereas the spores remained motile in water (not shown). All spores had encysted by $16 \mathrm{~h}$, when EGTA, EGTA $+\mathrm{Na}^{+}$or EGTA $+\mathrm{K}^{+}$had significantly suppressed germination, but EGTA $+\mathrm{Ca}^{2+}$ significantly enhanced germination over that in water controls. $\mathrm{EGTA}+\mathrm{Mg}^{2+}$ significantly enhanced germination only by $P$. aphanidermatum and $P$. dissotocum, and EGTA $+\mathrm{Sr}^{2+}$ only by $P$. aphanidermatum.

These experiments showed that adhesion was not necessary for germination if an appropriate divalent cation was supplied at high concentration, and $\mathrm{Mg}^{2+}$ or $\mathrm{Sr}^{2+}$ often substituted for $\mathrm{Ca}^{2+}$ in this respect.

\section{Effect of lanthanum on germination}

$\mathrm{La}^{3+}$ displaces $\mathrm{Ca}^{2+}$ from superficial binding sites and also blocks transmembrane fluxes of $\mathrm{Ca}^{2+}$ (Godfraind $e t$ al., 1986). When added to suspended cysts after 10 or 20 min, $\mathrm{La}^{3+}$ significantly suppressed germination to below the level in water controls (Table 6). This suppression was not relieved by post-treatment with $\mathrm{Ca}^{2+}$ or $\mathrm{Sr}^{2+}$. It was relieved by $\mathrm{Mg}^{2+}$, but only to the level in water controls, whereas $\mathrm{Mg}^{2+}$ significantly stimulated germination in the absence of $\mathrm{La}^{3+}$ (Table 6). $\mathrm{La}^{3+}$-suppression was relieved by a mixture of malt extract and peptone, which stimulated germination to the same level as it did in the absence of $\mathrm{La}^{3+}$. Identical results (not shown) were found when the cysts were centrifuged, and the pellet was rinsed and resuspended before the posttreatments were applied. $\mathrm{La}^{3+}$ should be removable by washing, but the rinses may not have been sufficient for this.

In further experiments (Table 7) suspended cysts were pretreated with $\mathrm{La}^{3+}$ or EGTA and then post-treated with L-amino acids known to stimulate germination (asparagine, aspartic acid and glutamic acid) or not to stimulate germination (lysine, glutamine) of $P$. aphanidermatum (Jones et al., 1991). Other post-treatments were included for comparison. The results were identical whether or not the cells were rinsed before posttreatment. Suppression by EGTA was reversed only by $\mathrm{Ca}^{2+}$ (the only ion tested), whereas suppression by $\mathrm{La}^{3+}$ was reversed only by the 'stimulatory' amino acids, not by $\mathrm{Ca}^{2+}$.

\section{Effects of calcium modulators}

Germination of suspended cysts of $P$. aphanidermatum was significantly suppressed (relative to water controls) by addition of verapamil, dibucaine, TFP, amiloride, TMB-8 or A23187 at $t_{10}$ or $t_{20}$ (Table 8). In every case the suppression was not relieved by post-treatment with $\mathrm{Ca}^{2+}, \mathrm{Mg}^{2+}$ or $\mathrm{Sr}^{2+}$, although these ions significantly enhanced germination when added to controls. Lysine (non-stimulatory) did not relieve the suppression, but asparagine (stimulatory) reversed the effects of verapamil, dibucaine, TFP and amiloride. In a further experiment, a combination of verapamil $(30 \mu \mathrm{M})$, dibucaine $(50 \mu \mathrm{M})$, amiloride $(20 \mu \mathrm{M})$, TFP $(5 \mu \mathrm{M})$ and $\mathrm{La}^{3+}$ $(0.75 \mathrm{mM})$ significantly reduced percentage germination from $24 \pm 2 \cdot 2$ (controls) to $5 \cdot 0 \pm 1 \cdot 4$. Asparagine reversed this suppression $(27 \cdot 8 \pm 3 \cdot 6$ per cent) but did not stimulate germination as it did with control cysts $(65 \cdot 0 \pm 5 \cdot 5)$. No post-treatment reversed the inhibition caused by TMB-8 or A23187 (Table 8).

Species-specificity of rescue by amino acids was found in a comparison of $P$. aphanidermatum with $P$. dissotocum 
Table 4. Effects of cations on germination of cysts held in suspension

Zoospores of three Pythium spp. were encysted by agitation, dispensed to Eppendorf tubes and treated with water (control) or $\mathrm{CaCl}_{2}, \mathrm{MgCl}_{2}, \mathrm{SrCl}_{2}, \mathrm{NaCl}$ or $\mathrm{KCl}$ at $1,5,7,10$ or $25 \mathrm{mM}$ final concentration. Percentage germination after $1.5 \mathrm{~h}$ and $16 \mathrm{~h}$ is shown as mean \pm SEM for seven replicates, 100 cysts each.

\begin{tabular}{|c|c|c|c|c|c|c|c|}
\hline \multirow[b]{3}{*}{ Treatment } & \multirow{3}{*}{$\underset{(\mathrm{mM})}{\text { Concn* }}$} & \multicolumn{6}{|c|}{ Germination $(\%)$} \\
\hline & & \multicolumn{2}{|c|}{ P. aphanidermatum } & \multicolumn{2}{|c|}{ P. catenulatum } & \multicolumn{2}{|c|}{ P. dissotocum } \\
\hline & & $1.5 \mathrm{~h}$ & $16 \mathrm{~h}$ & $1.5 \mathrm{~h}$ & $16 \mathrm{~h}$ & $1.5 \mathrm{~h}$ & $16 \mathrm{~h}$ \\
\hline $\mathrm{Ca}^{2+}$ & $\begin{array}{r}0 \\
1 \\
5 \\
7 \\
10 \\
25\end{array}$ & $\begin{array}{l}38 \pm 5 \cdot 2 \\
36 \pm 4 \cdot 1 \\
47 \pm 4 \cdot 9 \\
72 \pm 5 \cdot 0 \\
72 \pm 6 \cdot 1 \\
71 \pm 4 \cdot 3\end{array}$ & $\begin{array}{l}44 \pm 4 \cdot 1 \\
42 \pm 5 \cdot 0 \\
51 \pm 6 \cdot 1 \\
74 \pm 5 \cdot 0 \\
77 \pm 4 \cdot 8 \\
74 \pm 3 \cdot 8\end{array}$ & $\begin{array}{l}18 \pm 1 \cdot 6 \\
16 \pm 2 \cdot 6 \\
20 \pm 1 \cdot 6 \\
29 \pm 3 \cdot 9 \\
51 \pm 6 \cdot 9 \\
53 \pm 4 \cdot 2\end{array}$ & $\begin{array}{l}24 \pm 2 \cdot 1 \\
23 \pm 3 \cdot 9 \\
30 \pm 3 \cdot 1 \\
40 \pm 5 \cdot 5 \\
57 \pm 5 \cdot 9 \\
59 \pm 4 \cdot 1\end{array}$ & $\begin{array}{l}23 \pm 2 \cdot 3 \\
28 \pm 3 \cdot 9 \\
25 \pm 2 \cdot 8 \\
35 \pm 3 \cdot 2 \\
72 \pm 4 \cdot 2 \\
63 \pm 3 \cdot 3\end{array}$ & $\begin{array}{l}37 \pm 2 \cdot 9 \\
35 \pm 3 \cdot 3 \\
33 \pm 2 \cdot 1 \\
45 \pm 3 \cdot 8 \\
76 \pm 3 \cdot 6 \\
70 \pm 3 \cdot 0\end{array}$ \\
\hline $\mathbf{M g}^{2+}$ & $\begin{array}{r}0 \\
1 \\
5 \\
7 \\
10 \\
25\end{array}$ & $\begin{array}{l}30 \pm 3.4 \\
29 \pm 3.4 \\
36 \pm 5.8 \\
48 \pm 5.8 \\
67 \pm 7.6 \\
71 \pm 3.8\end{array}$ & $\begin{array}{l}36 \pm 3 \cdot 1 \\
34 \pm 3 \cdot 2 \\
40 \pm 5 \cdot 7 \\
56 \pm 4 \cdot 9 \\
70 \pm 6 \cdot 7 \\
76 \pm 2 \cdot 4\end{array}$ & $\begin{array}{l}20 \pm 2 \cdot 6 \\
21 \pm 2 \cdot 6 \\
20 \pm 2 \cdot 5 \\
30 \pm 2 \cdot 8 \\
49 \pm 6 \cdot 2 \\
59 \pm 6 \cdot 3\end{array}$ & $\begin{array}{l}28 \pm 2 \cdot 4 \\
28 \pm 2 \cdot 4 \\
27 \pm 2 \cdot 4 \\
43 \pm 4 \cdot 4 \\
57 \pm 5 \cdot 4 \\
65 \pm 4 \cdot 6\end{array}$ & $\begin{array}{l}28 \pm 2 \cdot 5 \\
30 \pm 3 \cdot 5 \\
28 \pm 2 \cdot 4 \\
37 \pm 3 \cdot 6 \\
57 \pm 4 \cdot 6 \\
57 \pm 3 \cdot 5\end{array}$ & $\begin{array}{l}32 \pm 3 \cdot 0 \\
38 \pm 3 \cdot 8 \\
34 \pm 2 \cdot 0 \\
46 \pm 2 \cdot 8 \\
66 \pm 4 \cdot 9 \\
64 \pm 4 \cdot 0\end{array}$ \\
\hline $\mathrm{Sr}^{2+}$ & $\begin{array}{r}0 \\
1 \\
5 \\
7 \\
10 \\
25\end{array}$ & $\begin{array}{l}39 \pm 3 \cdot 7 \\
38 \pm 2 \cdot 8 \\
46 \pm 4 \cdot 5 \\
50 \pm 5 \cdot 3 \\
60 \pm 6 \cdot 7 \\
72 \pm 3 \cdot 3\end{array}$ & $\begin{array}{l}43 \pm 5 \cdot 0 \\
42 \pm 3 \cdot 2 \\
52 \pm 3 \cdot 6 \\
58 \pm 5 \cdot 4 \\
65 \pm 5 \cdot 7 \\
78 \pm 2 \cdot 8\end{array}$ & $\begin{array}{l}22 \pm 1.9 \\
22 \pm 3 \cdot 1 \\
19 \pm 2 \cdot 4 \\
19 \pm 2 \cdot 3 \\
34 \pm 4.5 \\
54 \pm 4 \cdot 5\end{array}$ & $\begin{array}{l}30 \pm 3 \cdot 2 \\
32 \pm 2 \cdot 1 \\
25 \pm 2 \cdot 1 \\
29 \pm 2 \cdot 8 \\
44 \pm 4 \cdot 2 \\
60 \pm 4 \cdot 6\end{array}$ & $\begin{array}{l}23 \pm 3 \cdot 0 \\
21 \pm 3 \cdot 6 \\
22 \pm 2 \cdot 7 \\
27 \pm 2 \cdot 5 \\
53 \pm 4 \cdot 4 \\
49 \pm 6 \cdot 0\end{array}$ & $\begin{array}{l}29 \pm 3 \cdot 0 \\
28 \pm 3 \cdot 4 \\
27 \pm 2 \cdot 4 \\
32 \pm 2 \cdot 7 \\
61 \pm 4 \cdot 5 \\
56 \pm 5 \cdot 8\end{array}$ \\
\hline $\mathrm{Na}^{+} / \mathrm{K}^{+}+$ & $\begin{array}{r}0 \\
1 \\
5 \\
7 \\
10 \\
25\end{array}$ & $\begin{array}{l}38 \pm 3 \cdot 1 \\
36 \pm 6 \cdot 8 \\
43 \pm 6 \cdot 1 \\
41 \pm 3 \cdot 1 \\
40 \pm 6 \cdot 8 \\
40 \pm 7 \cdot 4\end{array}$ & $\begin{array}{l}43 \pm 3.8 \\
41 \pm 4 \cdot 6 \\
47 \pm 5.9 \\
48 \pm 1.7 \\
43 \pm 6.2 \\
46 \pm 6.8\end{array}$ & $\begin{array}{l}22 \pm 3 \cdot 0 \\
26 \pm 3 \cdot 7 \\
21 \pm 3 \cdot 9 \\
26 \pm 3 \cdot 2 \\
22 \pm 3 \cdot 6 \\
26 \pm 3 \cdot 5\end{array}$ & $\begin{array}{l}33 \pm 3 \cdot 3 \\
32 \pm 3 \cdot 2 \\
30 \pm 3 \cdot 7 \\
33 \pm 3 \cdot 2 \\
30 \pm 4 \cdot 0 \\
31 \pm 3 \cdot 3\end{array}$ & $\begin{array}{l}23 \pm 2 \cdot 2 \\
23 \pm 2 \cdot 5 \\
23 \pm 3 \cdot 3 \\
23 \pm 1 \cdot 9 \\
22 \pm 3 \cdot 1 \\
23 \pm 2 \cdot 1\end{array}$ & $\begin{array}{l}29 \pm 2.8 \\
31 \pm 1 \cdot 6 \\
31 \pm 2 \cdot 1 \\
30 \pm 2.3 \\
28 \pm 2 \cdot 3 \\
28 \pm 1.8\end{array}$ \\
\hline
\end{tabular}

* Each test with a cation had a designated water control.

$\dagger$ Combined data: the highest data point for $\mathrm{Na}^{+}$or $\mathrm{K}^{+}$is shown.

Table 5. Effects of EGTA with or without ions on cyst germination by three Pythium species

Cysts produced from zoospores by agitation were treated with EGTA, with or without cations (all at $10 \mathrm{~mm}$ final concentration) in Eppendorf tubes. Percentage germination after $1.5 \mathrm{~h}$ and $16 \mathrm{~h}$ is shown as mean \pm SEM for nine replicates, 100 cysts each.

\begin{tabular}{|c|c|c|c|c|c|c|}
\hline \multirow[b]{3}{*}{ Treatment } & \multicolumn{6}{|c|}{ Germination $(\%)$} \\
\hline & \multicolumn{2}{|c|}{ P. aphanidermatum } & \multicolumn{2}{|c|}{ P. dissotocum } & \multicolumn{2}{|c|}{ P. catenulatum } \\
\hline & $1.5 \mathrm{~h}$ & $16 \mathrm{~h}$ & $1 \cdot 5 \mathrm{~h}$ & $16 \mathrm{~h}$ & $1.5 \mathrm{~h}$ & $16 \mathrm{~h}$ \\
\hline None (water) & $35 \pm 6 \cdot 7$ & $38 \pm 6 \cdot 5$ & $20 \pm 2 \cdot 7$ & $29 \pm 2 \cdot 3$ & $24 \pm 1 \cdot 7$ & $30 \pm 2 \cdot 4$ \\
\hline EGTA* & $3 \pm 0.8$ & $15 \pm 2 \cdot 0$ & $5 \pm 1 \cdot 1$ & $11 \pm 2 \cdot 0$ & $4 \pm 1.6$ & $15 \pm 1 \cdot 7$ \\
\hline $\mathrm{Na}^{+} / \mathrm{EGTA}^{*}$ & $4 \pm 1 \cdot 0$ & $13 \pm 2 \cdot 2$ & $6 \pm 1 \cdot 3$ & $11 \pm 2 \cdot 0$ & $5 \pm 1 \cdot 1$ & $16 \pm 2 \cdot 0$ \\
\hline $\mathrm{K}^{+} / \mathrm{EGTA}^{*}$ & $4 \pm 1 \cdot 3$ & $16 \pm 3.7$ & $6 \pm 1 \cdot 1$ & $13 \pm 2 \cdot 4$ & $7 \pm 1 \cdot 4$ & $16 \pm 3.7$ \\
\hline $\mathrm{Ca}^{2+} /$ EGTA & $48 \pm 6.5$ & $67 \pm 4 \cdot 4$ & $37 \pm 4 \cdot 3$ & $54 \pm 7 \cdot 1$ & $37 \pm 5.4$ & $55 \pm 5.9$ \\
\hline $\mathrm{Mg}^{2+} /$ EGTA & $55 \pm 6 \cdot 8$ & $67 \pm 5 \cdot 3$ & $28 \pm 4 \cdot 6$ & $43 \pm 4 \cdot 2$ & $26 \pm 2 \cdot 5$ & $45 \pm 5.6$ \\
\hline $\mathrm{Sr}^{2+} /$ EGTA & $40 \pm 4 \cdot 8$ & $54 \pm 4 \cdot 8$ & $25 \pm 2 \cdot 8$ & $42 \pm 5 \cdot 0$ & $22 \pm 2 \cdot 5$ & $41 \pm 3 \cdot 5$ \\
\hline
\end{tabular}

* Significantly different from water controls in all cases.

(Table 9). Asparagine rescued cysts of both fungi from suppression by verapamil or dibucaine, but alanine rescued only $P$. dissotocum, consistent with its ability to stimulate germination of control cysts of this fungus.

\section{Discussion}

Pythium and Phytophthora are closely related genera, with a fundamentally similar infection sequence from 
Table 6. Effects of lanthanum and post-treatment with other substances on cyst germination by Pythium aphanidermatum

Zoospores encysted by agitation and held in suspension were treated after $10 \mathrm{~min}$ with $\mathrm{La}^{3+}$ and post-treated (at $20 \mathrm{~min}$ ) as shown. Percentage germination after $1.5 \mathrm{~h}$ and $16 \mathrm{~h}$ is shown as mean \pm SEM for seven replicates, 100 cysts each.

\begin{tabular}{|c|c|c|c|}
\hline \multirow{2}{*}{$\begin{array}{l}\text { Treatment } \\
(1.5 \mathrm{mM})\end{array}$} & \multirow{2}{*}{$\begin{array}{c}\text { Post-treatment } \\
\text { (10 mM unless stated) }\end{array}$} & \multicolumn{2}{|c|}{ Germination $(\%)$} \\
\hline & & $1.5 \mathrm{~h}$ & $16 \mathrm{~h}$ \\
\hline None & $\begin{array}{l}\text { None } \\
\mathrm{Ca}^{2+} \\
\mathrm{Sr}^{2+} \\
\mathrm{Mg}^{2+} \\
\mathrm{La}^{3+}(1.5 \mathrm{mM}) \\
\mathrm{La}^{3+}(1.5 \mathrm{mM})+\mathrm{Ca}^{2+} \\
\mathrm{MEP}^{*}\end{array}$ & $\begin{array}{r}19 \pm 2 \cdot 0 \\
47 \pm 4 \cdot 6 \\
36 \pm 3 \cdot 0 \\
39 \pm 3 \cdot 7 \\
4 \pm 1 \cdot 1 \\
7 \pm 1 \cdot 1 \\
47 \pm 4 \cdot 6\end{array}$ & $\begin{array}{r}22 \pm 2 \cdot 9 \\
51 \pm 3 \cdot 6 \\
40 \pm 2 \cdot 7 \\
42 \pm 3 \cdot 5 \\
5 \pm 1 \cdot 3 \\
9 \pm 0.9 \\
47 \pm 2 \cdot 2\end{array}$ \\
\hline $\mathrm{La}^{3+}$ & $\begin{array}{l}\text { None } \\
\mathrm{Ca}^{2+} \\
\mathrm{Sr}^{2+} \\
\mathrm{Mg}^{2+} \\
\mathrm{La}^{3+}(1.5 \mathrm{mM}) \\
\mathrm{La}^{3+}(1.5 \mathrm{mM})+\mathrm{Ca}^{2+} \\
\mathrm{MEP}^{*}\end{array}$ & $\begin{array}{r}8 \pm 1 \cdot 3 \\
12 \pm 2 \cdot 4 \\
12 \pm 1 \cdot 3 \\
23 \pm 3 \cdot 3 \\
5 \pm 1 \cdot 2 \\
8 \pm 1 \cdot 0 \\
40 \pm 7 \cdot 3\end{array}$ & $\begin{array}{r}11 \pm 1 \cdot 6 \\
14 \pm 2 \cdot 2 \\
14 \pm 1 \cdot 8 \\
27 \pm 3 \cdot 3 \\
8 \pm 1 \cdot 3 \\
12 \pm 0 \cdot 9 \\
46 \pm 2 \cdot 2\end{array}$ \\
\hline
\end{tabular}

* MEP, malt extract $(3 \%)+$ peptone $(1 \%)$. zoospores (e.g. Deacon, 1988). Here, $P$. aphanidermatum was found to behave like Ph. cinnamomi (Gubler et al., 1989 ) in adhesion. New cysts naturally adhered to a surface, but this was prevented by EGTA; older cysts lost their adhesiveness in the absence of a surface, but it was restored by addition of $\mathrm{Ca}^{2+}$. In explanation of this, Gubler et al. (1989) proposed that $\mathrm{Ca}^{2+}$ interacts with cyst coat glycoprotein for adhesion to surfaces. The $\mathrm{Ca}^{2+}$ was assumed to be released early in encystment, as Irving et al. (1984) showed for Ph. palmivora, and loss of adhesiveness with age of non-attached cells probably occurred by dispersion of the released $\mathrm{Ca}^{2+}$.

$\mathrm{Ca}^{2+}$ and other divalent cations promote germination by Phytophthora spp., as now confirmed for Pythium. Here, cysts that had adhered needed no further trigger for germination, but even young $\left(t_{0}\right)$ non-attached cysts required an exogenous factor such as a divalent cation (7-10 mM) or specific amino acids (Tables 4-7). Selfsufficiency for germination was retained during 4-5 min delay in contacting a surface but lost after 7 min delay (Table 2); adhesion for the initial $10 \mathrm{~min}$ was sufficient to

Table 7. Rescue of lanthanum- or EGTA-suppressed germination of cysts of $P$. aphanidermatum by calcium and amino acids

Zoospores encysted by agitation were treated 10 min later with $\mathrm{La}^{3+}$ or EGTA then post-treated at 20 min as shown. Percentage germination after $1.5 \mathrm{~h}$ or $16 \mathrm{~h}$ is shown as mean \pm SEM for seven replicates, 100 cysts each, in two separate experiments.

\begin{tabular}{|c|c|c|c|c|c|}
\hline \multirow[b]{3}{*}{ Treatment (mM) } & \multirow{3}{*}{$\begin{array}{l}\text { Post-treatment } \\
\text { (10 mM unless shown) }\end{array}$} & \multicolumn{4}{|c|}{ Germination (\%) } \\
\hline & & \multicolumn{2}{|c|}{ Experiment 1} & \multicolumn{2}{|c|}{ Experiment 2} \\
\hline & & $1.5 \mathrm{~h}$ & $16 \mathrm{~h}$ & $1.5 \mathrm{~h}$ & $16 \mathrm{~h}$ \\
\hline None & $\begin{array}{l}\text { None } \\
\text { EGTA (7 mM) } \\
\mathrm{La}^{3+}(1.5 \mathrm{~mm}) \\
\mathrm{Ca}^{2+} \\
\text { Asparagine } \\
\text { Glutamine } \\
\text { Glutamic acid } \\
\text { Aspartic acid } \\
\text { Lysine }\end{array}$ & $\begin{aligned} 21 & \pm 1 \cdot 4 \\
8 & \pm 0 \cdot 8 \\
9 & \pm 0 \cdot 8 \\
61 & \pm 4 \cdot 6 \\
71 & \pm 4 \cdot 8 \\
23 & \pm 1 \cdot 8 \\
& - \\
& - \\
& -\end{aligned}$ & $\begin{array}{l}25 \pm 1 \cdot 1 \\
10 \pm 0 \cdot 8 \\
12 \pm 1 \cdot 0 \\
64 \pm 5 \cdot 1 \\
75 \pm 3 \cdot 4 \\
25 \pm 1 \cdot 3 \\
- \\
- \\
-\end{array}$ & $\begin{array}{r}20 \pm 1 \cdot 9 \\
9 \pm 1 \cdot 6 \\
9 \pm 1 \cdot 0 \\
57 \pm 5 \cdot 3 \\
53 \pm 5 \cdot 3 \\
- \\
46 \pm 4 \cdot 2 \\
48 \pm 3 \cdot 9 \\
18 \pm 2 \cdot 8\end{array}$ & $\begin{array}{c}25 \pm 1 \cdot 7 \\
13 \pm 2 \cdot 2 \\
15 \pm 1 \cdot 3 \\
63 \pm 3 \cdot 9 \\
61 \pm 5 \cdot 2 \\
- \\
53 \pm 4 \cdot 7 \\
56 \pm 4 \cdot 7 \\
28 \pm 1 \cdot 5\end{array}$ \\
\hline EGTA (7) & $\begin{array}{l}\text { None } \\
\text { EGTA (7 mM) } \\
\mathrm{La}^{3+}(1.5 \mathrm{mM}) \\
\mathrm{Ca}^{2+} \\
\text { Asparagine } \\
\text { Glutamine } \\
\text { Glutamic acid } \\
\text { Aspartic acid } \\
\text { Lysine }\end{array}$ & $\begin{aligned} 8 & \pm 1 \cdot 0 \\
9 & \pm 0 \cdot 8 \\
7 & \pm 0 \cdot 8 \\
56 & \pm 5 \cdot 4 \\
10 & \pm 1 \cdot 0 \\
9 & \pm 0 \cdot 8 \\
& - \\
& - \\
& -\end{aligned}$ & $\begin{array}{r}11 \pm 1.0 \\
12 \pm 0.7 \\
9 \pm 0.6 \\
60 \pm 4.5 \\
13 \pm 1.6 \\
13 \pm 1.8 \\
- \\
- \\
-\end{array}$ & $\begin{array}{r}11 \pm 0 \cdot 9 \\
10 \pm 0.9 \\
7 \pm 1 \cdot 0 \\
38 \pm 3 \cdot 5 \\
13 \pm 2 \cdot 1 \\
- \\
10 \pm 1 \cdot 4 \\
14 \pm 1 \cdot 9 \\
8 \pm 1 \cdot 1\end{array}$ & $\begin{array}{c}15 \pm 1 \cdot 5 \\
14 \pm 1 \cdot 3 \\
12 \pm 1 \cdot 3 \\
42 \pm 3 \cdot 7 \\
19 \pm 2 \cdot 4 \\
- \\
16 \pm 1 \cdot 0 \\
17 \pm 2 \cdot 2 \\
14 \pm 1 \cdot 9\end{array}$ \\
\hline $\mathrm{La}^{3+}(1 \cdot 5)$ & $\begin{array}{l}\text { None } \\
\text { EGTA (7 mM) } \\
\mathrm{La}^{3+}(1.5 \mathrm{~mm}) \\
\mathrm{Ca}^{2+} \\
\text { Asparagine } \\
\text { Glutamine } \\
\text { Glutamic acid } \\
\text { Aspartic acid } \\
\text { Lysine }\end{array}$ & $\begin{aligned} & 9 \pm 0 \cdot 9 \\
& 6 \pm 0 \cdot 5 \\
& 6 \pm 1 \cdot 1 \\
& 9 \pm 1 \cdot 6 \\
& 43 \pm 4 \cdot 3 \\
& 10 \pm 1 \cdot 1 \\
&- \\
&- \\
&-\end{aligned}$ & $\begin{aligned} & 12 \pm 1 \cdot 3 \\
& 8 \pm 0.8 \\
& 9 \pm 0.9 \\
& 11 \pm 0.7 \\
& 48 \pm 3.9 \\
& 13 \pm 0.8 \\
&- \\
&- \\
&-\end{aligned}$ & $\begin{array}{r}10 \pm 1 \cdot 0 \\
9 \pm 0 \cdot 8 \\
8 \pm 1 \cdot 0 \\
14 \pm 2 \cdot 3 \\
37 \pm 4 \cdot 6 \\
- \\
33 \pm 2 \cdot 4 \\
40 \pm 4 \cdot 1 \\
9 \pm 1 \cdot 1\end{array}$ & $\begin{array}{c}14 \pm 1 \cdot 5 \\
14 \pm 1 \cdot 8 \\
13 \pm 1 \cdot 6 \\
17 \pm 2 \cdot 1 \\
42 \pm 3 \cdot 7 \\
- \\
38 \pm 3 \cdot 3 \\
46 \pm 5 \cdot 2 \\
14 \pm 1 \cdot 3\end{array}$ \\
\hline
\end{tabular}


Table 8. Effects of calcium modulators on germination of cysts of Pythium aphanidermatum

Zoospores encysted by agitation were treated 10 min later with calcium modulators then post-treated at 20 min as shown. Percentage germination after $16 \mathrm{~h}$ is shown as mean \pm SEM for five replicates, 100 cysts each.

\begin{tabular}{|c|c|c|c|c|c|c|c|}
\hline \multirow[b]{3}{*}{ Post-treatment $\uparrow$} & \multicolumn{7}{|c|}{ Germination $(\%)$} \\
\hline & \multicolumn{7}{|c|}{ Treatment $(\mu \mathrm{M})^{*}$ : } \\
\hline & None & $\begin{array}{l}\text { Verapamil } \\
(30)\end{array}$ & $\begin{array}{l}\text { TFP } \\
(5)\end{array}$ & $\begin{array}{l}\text { Dibucaine } \\
\quad(50)\end{array}$ & $\underset{(5)}{\mathrm{A} 23187}$ & $\begin{array}{l}\text { Amiloride } \\
(20)\end{array}$ & $\begin{array}{c}\text { TMB-8 } \\
\text { (30) }\end{array}$ \\
\hline None (water) & $24 \pm 3 \cdot 4$ & $10 \pm 1 \cdot 6$ & $9 \pm 4 \cdot 0$ & $5 \pm 1.4$ & $5 \pm 0.9$ & $6 \pm 1 \cdot 1$ & $11 \pm 2 \cdot 3$ \\
\hline $\mathrm{Ca}^{2+}$ & $55 \pm 5 \cdot 5$ & $6 \pm 1.6$ & $10 \pm 2 \cdot 5$ & $8 \pm 1 \cdot 4$ & $9 \pm 1 \cdot 3$ & $5 \pm 1.5$ & $9 \pm 2.8$ \\
\hline $\mathbf{M g}^{2+}$ & $39 \pm 3.9$ & $7+1.5$ & $12+3 \cdot 0$ & $6+1.4$ & $6+1.6$ & $6+2 \cdot 4$ & $9+2 \cdot 8$ \\
\hline $\mathrm{Sr}^{2+}$ & $46 \pm 2 \cdot 9$ & $9 \pm 1.8$ & $15 \pm 4 \cdot 0$ & $6 \pm 1 \cdot 0$ & $3 \pm 1.7$ & $8 \pm 3 \cdot 6$ & $7 \pm 1.4$ \\
\hline Asparagine & $66 \pm 5 \cdot 7$ & $53 \pm 5.6$ & $75 \pm 6 \cdot 5$ & $61 \pm 9.7$ & $6 \pm 1.4$ & $69 \pm 4.6$ & $6 \pm 1.9$ \\
\hline Lysine & $19 \pm 1 \cdot 4$ & $10 \pm 1.5$ & $10 \pm 2 \cdot 6$ & $8 \pm 2.4$ & $5 \pm 1 \cdot 1$ & $7 \pm 1 \cdot 2$ & $8 \pm 1 \cdot 1$ \\
\hline Verapamil & $8 \pm 1.5$ & $8 \pm 1.0$ & \pm & - & - & - & 1 \\
\hline TFP & $12 \pm 2 \cdot 3$ & - & $12 \pm 2 \cdot 0$ & - & - & - & - \\
\hline Dibucaine & $11+2 \cdot 1$ & _- & - & $5+1 \cdot 1$ & - & _- & _- \\
\hline A 23187 & $6 \pm 1 \cdot 2$ & - & - & - & $4 \pm 1 \cdot 3$ & - & - \\
\hline Amiloride & $10 \pm 2 \cdot 3$ & - & - & - & 1 & $6 \pm 1 \cdot 4$ & - \\
\hline TMB-8 & $11 \pm 2.8$ & - & - & - & - & I & $6 \pm 1 \cdot 0$ \\
\hline
\end{tabular}

* In the absence of post-treatment, all treatment compounds significantly suppressed germination compared with water controls.

$\dagger$ Post-treatments were at $10 \mathrm{mM}$ final concentration except for calcium modulators, which were used at the same concentrations as for treatments.

Table 9. Reversal of suppression by verapamil and dibucaine in Pythium aphanidermatum and $P$. dissotocum

Zoospores encysted by agitation were treated $10 \mathrm{~min}$ later with verapamil or dibucaine, then post-treated at $20 \mathrm{~min}$ as shown. Percentage germination after $16 \mathrm{~h}$ is shown as mean \pm SEM for five replicates, 100 cysts each.

\begin{tabular}{|c|c|c|c|c|c|c|}
\hline \multirow[b]{3}{*}{$\begin{array}{l}\text { Post-treatment } \\
\quad(10 \mathrm{mM})\end{array}$} & \multicolumn{6}{|c|}{ Germination $(\%)$} \\
\hline & \multicolumn{3}{|c|}{ P. aphanidermatum } & \multicolumn{3}{|c|}{ P. dissotocum } \\
\hline & $\begin{array}{c}\text { No } \\
\text { treatment }\end{array}$ & $\begin{array}{l}\text { Verapamil } \\
\quad(30 \mu \mathrm{M})\end{array}$ & $\begin{array}{l}\text { Dibucaine } \\
(50 \mu \mathrm{M})\end{array}$ & $\begin{array}{c}\text { No } \\
\text { treatment }\end{array}$ & $\begin{array}{l}\text { Verapamil } \\
(30 \mu \mathrm{M})\end{array}$ & $\begin{array}{l}\text { Dibucaine } \\
(50 \mu \mathrm{M})\end{array}$ \\
\hline $\begin{array}{l}\text { None (water) } \\
\mathrm{Ca}^{2+} \\
\text { Asparagine } \\
\text { Alanine }\end{array}$ & $\begin{array}{l}20 \pm 3 \cdot 8 \\
42 \pm 5 \cdot 4 \\
64 \pm 9 \cdot 2 \\
18 \pm 2 \cdot 4\end{array}$ & $\begin{array}{r}9 \pm 0.9 \\
7 \pm 1 \cdot 1 \\
63 \pm 7.6 \\
12 \pm 2.6\end{array}$ & $\begin{array}{r}6 \pm 0.7 \\
7 \pm 1.4 \\
45 \pm 6.1 \\
8 \pm 2.1\end{array}$ & $\begin{array}{l}23 \pm 2 \cdot 6 \\
54 \pm 3 \cdot 8 \\
66 \pm 6 \cdot 3 \\
41 \pm 5 \cdot 0\end{array}$ & $\begin{array}{r}7 \pm 2 \cdot 3 \\
9 \pm 2 \cdot 5 \\
47 \pm 6 \cdot 1 \\
26 \pm 1 \cdot 3\end{array}$ & $\begin{array}{r}4 \pm 1.0 \\
4 \pm 1.9 \\
52 \pm 8.9 \\
28 \pm 4.4\end{array}$ \\
\hline
\end{tabular}

enable germination because cysts could then be dislodged without effect (although adhesion is effectively permanent in nature). The flux of $\mathrm{Ca}^{2+}$ across the cyst membrane, measured for Ph. palmivora, is sufficient to explain this : up to $30 \%$ of cell $\mathrm{Ca}^{2+}$ was released within 2 min of encystment (Irving et al., 1984) and labelled $\mathrm{Ca}^{2+}$ was taken up within 2 min (Iser et al., 1989). Both $\mathrm{Sr}^{2+}$ and $\mathrm{Mg}^{2+}$ were found to substitute for $\mathrm{Ca}^{2+}$ in promoting germination of Pythium (Table 4). However, the suppression of germination by EGTA was almost certainly caused by chelation of $\mathrm{Ca}^{2+}$, because the stability constant for binding of EGTA to $\mathrm{Ca}^{2+}$ is at least five orders of magnitude higher than for $\mathrm{Mg}^{2+}$, and nearly three orders of magnitude higher than for $\mathrm{Sr}^{2+}(\mathrm{Schmid}$
\& Reilley, 1957). The effects of the $\mathrm{Ca}^{2+}$ entry blockers $\mathrm{La}^{3+}$ and verapamil (Godfraind et al., 1986) supported a central role of $\mathrm{Ca}^{2+}$ uptake in germination. The low background germination of suspended cysts seemed to depend on uptake of $\mathrm{Ca}^{2+}$ over a prolonged time because EGTA suppressed germination even when added at 20 min (Table 7).

These findings can be related to behaviour in vivo by a simple model. Zoospores dock and encyst precisely on roots, such that the fixed point of germination is next to the host (Hardham \& Gubler, 1990; Jones et al., 1991) and the glycoprotein secreted over the germination site adheres the cyst in this orientation (Hardham \& Gubler, 1990). As on slides, adhesion is likely to involve $\mathrm{Ca}^{2+}$, 
released during encystment, and adhesion should then impede dispersion of $\mathrm{Ca}^{2+}$ from the germination site, perhaps by ionic bridging but at least by lengthening the diffusion path. $\mathrm{Ca}^{2+}$ could then be reabsorbed and trigger germination. Thus, docking would lead automatically to germination, independent of other triggers, as when cysts adhere to glass, and the orientation of germination would lead automatically to host-penetration. The zoospore is thus envisaged to have an in-built reporter system to signal that it has docked correctly, and infection follows by a $\mathrm{Ca}^{2+}$-mediated cascade.

A corollary of this hypothesis is that the predetermined site of germination is a control centre which receives the $\mathrm{Ca}^{2+}$ signal. This is not essential because, theoretically, adhesion and $\mathrm{Ca}^{2+}$ uptake might occur at any point on the cyst surface in vitro. But in vivo docking will ensure that it invariably involves the germination site. The possibility of a control centre might focus future work. Gubler et al. (1990) found localized intense antibody reaction for calmodulin on the knob-like base of the anterior flagellum of Ph. cinnamomi, which is near the point of germ-tube outgrowth of both Phytophthora (Paktitis et al., 1986) and Pythium (Jones et al., 1991). It is unknown whether the knob-like base is retained when flagella are shed and whether calmodulin is similarly localized in Pythium. Nevertheless, germination of Pythium was suppressed by dibucaine and TFP, which are calmodulin inhibitors in mammalian systems (Bereza et al., 1982). The region of flagellar insertion is also rich in microtubules (Grove \& Bracker, 1978) and associated proteins, which are widely implicated in signal transduction.

Specific amino acids triggered germination, but were not effective in the presence of EGTA (Table 7), suggesting that their actions were intimately linked with $\mathrm{Ca}^{2+}$ uptake or $\mathrm{Ca}^{2+}$ signalling at the cell surface. Consistent with this, the amino acids reversed the suppression caused by calcium entry blockers $\left(\mathrm{La}^{3+}\right.$, verapamil) or by amiloride, which inhibits $\mathrm{Na}^{+} / \mathrm{Ca}^{2+}$ flux across membranes of mammalian cells (Godfraind et al., 1986) and can also block $\mathrm{Ca}^{2+}$ channels (Tytgat $e t$ al., 1990). The same amino acids reversed the suppression caused by calmodulin inhibitors (dibucaine, TFP), but did not overcome suppression by TMB-8, an intracellular calcium antagonist in mammalian systems (Owen \& Villereal, 1982). The failure of amino acids or even $\mathrm{Ca}^{2+}$ to reverse suppression by A23187 is not easily explained. A23187 is an ionophore (Pressman, 1976) and should cause equilibration of $\mathrm{Ca}^{2+}$ across the cell membrane. Irving et al. (1984) found that it induced encystment and germination of Phytophthora zoospores in the presence of $1 \mathrm{~mm}-\mathrm{Ca}^{2+}$, but not with $100 \mu \mathrm{M}-\mathrm{Ca}^{2+}$, presumably because equilibration of $\mathrm{Ca}^{2+}$ at this concentration was too low to induce differentiation. In our study, $10 \mathrm{~mm}-\mathrm{Ca}^{2+}$ did not reverse suppression of Pythium by A23187 (Table 8), perhaps because equilibration of $\mathrm{Ca}^{2+}$ at this concentration was toxic or A23187 had inhibitory effects unrelated to $\mathrm{Ca}^{2+}$ fluxes.

Amino acids are unlikely to have been taken up by the cysts, because Penington et al. (1989) found no significant uptake of labelled glutamate by zoospores or cysts of $P h$. palmivora until after germination, and we (unpublished) found no evidence of uptake of labelled glutamate by spores of $P$. aphanidermatum. This would preclude the uptake of $\mathrm{Ca}^{2+}$ by symport and indicates, instead, that amino acids acted through receptors on the cyst membrane to open $\mathrm{Ca}^{2+}$ channels. $\mathrm{Ca}^{2+}$-channel-linked glutamate receptors are widely reported in other organisms (e.g. Gilbertson et al., 1991; Hollmann et al., 1991) and might be expected to occur in Oomycete zoospores. To our knowledge, $\mathrm{Ca}^{2+}$ channels linked to aspartate, asparagine or alanine receptors have not been reported before. In any case, a receptor-mediated role of amino acids would be consistent with their species-specific effects, as found for alanine in this work (Table 9).

The question remains as to how amino acids might influence germination on roots. They are not essential, because young adherent cysts needed no supplementary trigger in vitro. Nevertheless, if amino acids can open $\mathrm{Ca}^{2+}$ channels, then they could synergize $\mathrm{Ca}^{2+}$ uptake during the docking sequence on roots. This could explain the common observation (e.g. Jones et al., 1991) that cysts germinate rapidly and with almost $100 \%$ efficiency on roots, in contrast to the maximum of approximately $70 \%$ germination in this study.

We thank the Natural Environment Research Council for a Studentship to S.P.D. during this work, and Professor M. E. Stanghellini for supplying isolates

\section{References}

Bereza, U. L., Brewer, G. J. \& Mizukami, I. (1982). Association of calmodulin inhibition with erythrocyte membrane stabilization and pharmacological effects of drugs. Biochimica et Biophysica Acta 692, 305-314.

Byrt, P. N., Irving, H. R. \& Grant, B. R. (1982). The effect of cations on zoospores of the fungus Phytophthora cinnamomi. Journal of General Microbiology 128, 1189-1198.

DEACON, J. W. (1988). Behavioural responses of fungal zoospores. Microbiological Sciences 5, 249-252.

Estrada-Garcia, M. T., Callow, J. A. \& Green, J. R. (1990). Monoclonal antibodies to the adhesive cell coat secreted by Pythium aphanidermatum zoospores recognise $200 \times 10^{3} M_{\mathrm{r}}$ glycoproteins stored within large peripheral vesicles. Journal of Cell Science 95, 199-206.

Gilbertson, T. A., SCOBEy, R. \& Wilson, M. (1991). Permeation of calcium ions through non-NMDA-glutamate channels in retinal bipolar cells. Science 251, 1613-1615.

Godfraind, T., Miller, R. \& Wibo, M. (1986). Calcium antagonism and calcium entry blockage. Pharmacological Reviews 38, 321-416. 
Goldberg, N. P., Hawes, M. C. \& Stanghellini, M. E. (1989). Specific attraction to and infection of cotton root cap cells by zoospores of Pythium dissotocum. Canadian Journal of Botany 67, 1760-1767.

Grant, B. R., Griffith, J. M. \& IRving, H. R. (1986). A model to explain ion-induced differentiation in zoospores of Phytophthora palmivora. Experimental Mycology 10, 89-98.

Grove, S. N. \& Bracker, C. E. (1978). Protoplasmic changes during zoospore encystment and cyst germination in Pythium aphanidermatum. Experimental Mycology 2, 51-98.

GUBLER, F. \& HARDHAM, A. R. (1988). Secretion of adhesive material during encystment of Phytophthora cinnamomi zoospores, characterized by immunogold labelling with monoclonal antibodies to components of peripheral vesicles. Journal of Cell Science 90, 225 235.

GubleR, F. \& HaRdHAM, A. R. (1991). The fate of peripheral vesicles in zoospores of Phytophthora cinnamomi during infection of plants. In Electron Microscopy of Plant Pathogens, pp. 197-210. Edited by K. Mengden \& D. E. Lesemann. London: Springer-Verlag.

Gubler, F., Hardham, A. R. \& Duniec, J. (1989). Characterizing adhesiveness of Phytophthora cinnamomi zoospores during encystment. Protoplasma 149, 24-30.

Gubler, F., Jablonsky, P. P., Duniec, J. \& Hardham, A. R. (1990). Localization of calmodulin in flagella of zoospores of Phytophthora cinnamomi. Protoplasma 155, 233-238.

Hardham, A. R. \& Gubler, F. (1990). Polarity of attachment of zoospores of a root pathogen and pre-alignment of the emerging germ tube. Cell Biology International Reports 14, 947-956.

Hinch, J. M. \& Clarke, A. E. (1980). Adhesion of fungal zoospores to root surfaces is mediated by carbohydrate determinants of the root slime. Physiological Plant Pathology 16, 303-307.

HollmanN, M., Hartley, M. \& HeinemanN, S. (1991). $\mathrm{Ca}^{2+}$ permeability of KA-AMPA-gated glutamate receptor channels depends on subunit composition. Science 252, 851-853.

IRVING, H. R. \& GRANT, B. R. (1984). The effect of calcium on zoospore differentiation in Phytophthora cinnamomi. Journal of General Microbiology 130, 1569-1576.

IRviNG, H. R., GrifFith, J. M. \& Grant, B. R. (1984). Calcium efflux associated with encystment of Phytophthora palmivora zoospores. Cell Calcium 5, 487-500.

Iser, J. R., Griffith, J. M., Balson, A. \& Grant, B. R. (1989). Accelerated ion fluxes during differentiation in zoospores of Phytophthora palmivora. Cell Differentiation and Development 26, 2938.
Jones, S. W., Donaldson, S. P. \& Deacon, J. W. (1991). Behaviour of zoospores and zoospore cysts in relation to root infection by Pythium aphanidermatum. New Phytologist 117, 289-301.

Longman, D. \& CALlow, J. A. (1987). Specific saccharide residues are involved in the recognition of plant root surfaces by zoospores of Pythium aphanidermatum. Physiological and Molecular Plant Pathology 30, 139-150.

Mitchell, R. T. \& DeAcon, J. W. (1986a). Chemotropism of germtubes from zoospore cysts of Pythium spp. Transactions of the British Mycological Society 86, 233-237.

Mitchell, R. T. \& Deacon, J. W. (1986 b). Differential (host-specific) accumulation of zoospores of Pythium on roots of graminaceous and non-graminaceous plants. New Phytologist 102, 113-122.

MrtChell, R. T. \& Deacon, J. W. (1986c). Selective accumulation of zoospores of chytridiomycetes and oomycetes on cellulose and chitin. Transactions of the British Mycological Society 86, 219-223.

OWEN, N. E. \& Villereal, M. L. (1982). The effect of the intracellular antagonist TMB-8 on serum stimulated sodium influx in human fibroblasts. Biochemical and Biophysical Research Communications 109, 762-768.

Paktitis, S., Grant, B. \& Lawrie, A. (1986). Surface changes in Phytophthora palmivora zoospores following induced differentiation. Protoplasma 135, 119-129.

Penington, C. J., Iser, J. R., Grant, B. R. \& Gayler, K. R. (1989). Role of RNA and protein synthesis in stimulated germination of zoospores of the pathogenic fungus Phytophthora palmivora. Experimental Mycology 13, 158-168.

Pressman, B. C. (1976). Biological applications of ionophores. Annual Review of Biochemistry 45, 501-530.

SCHMID, R. W. \& ReILlEy, C. N. (1957). New complexon for titration of calcium in the presence of magnesium. Analytical Chemistry 29, 264-268.

Sing, V. O. \& Bartnicki-Garcia, S. (1975). Adhesion of Phytophthora palmivora zoospores : electron microscopy of cell attachment and cyst wall fibril formation. Journal of Cell Science 18, 123-132.

SNEDECOR, G. W. \& Cochrane, W. G. (1980). Statistical Methods, 7th edn. Ames, Iowa: Iowa State University Press.

ToKUNAGA, J. \& BARTNICKI-GARCIA, S. (1971). Cyst wall formation and endogenous carbohydrate utilisation during synchronous encystment of Phytophthora palmivora zoospores. Archiv für Mikrobiologie 79, 282-292.

Tytgat, J., Vereecke, J. \& Carmeliet, E. (1990). Mechanism of cardiac T-type Ca channel blockade by amiloride. Journal of Pharmacology and Experimental Therapeutics 254, 546-551. 